\title{
EFFECT OF GUTTING ON RANCIDITY DEVELOPMENT IN HORSE MACKEREL (Trachurus trachurus) DURING FROZEN STORAGE
}

\author{
Ines Lehmann ${ }^{1, *}$ and Santiago P. Aubourg ${ }^{2}$ \\ ${ }^{1}$ Bundesforschunganstalt für Fischerei. Institut für Fischereitechnik and Fischqualität. \\ Palmaille, 9 D-22767 Hamburg (Germany) \\ 2 Instituto de Investigaciones Marinas (CSIC). C/ Eduardo Cabello, 6 E-36208 Vigo \\ (Spain) \\ ${ }^{*}$ Correspondent: FAX and e-mail
}

Running Title: Gutting and frozen horse mackerel rancidity

Key Words: Horse mackerel, gutting, frozen storage, rancidity, quality

\section{SUMMARY}

Gutting handling was applied to fresh horse mackerel (Trachurus trachurus) to study its effect on rancidity development during the frozen storage (up to 12 months at $20^{\circ} \mathrm{C}$ ). For it, chemical (free fatty acids, FFA; peroxide value, PV; thiobarbituric acid index, TBA-i; fluorescence ratio, FR) and sensory (odour and taste) analyses were carried out. Results showed that gutting treatment of horse mackerel previously to frozen storage led to a higher oxidation development in the frozen product, according to chemical (PV, TBA-i and FR) and sensory (odour and taste) analyses. However, a lower lipid hydrolysis (FFA formation) could be detected in gutted fish at the end of the storage (month 12). It is concluded that gutting of a medium-fat content fish species as horse mackerel is not recommended as a previous treatment to frozen storage.

\section{INTRODUCTION}

Freezing and frozen storage have been widely employed to retain fish properties before it is consumed (Pigott and Tucker, 1987; Madrid et al., 1994). However, during the frozen storage of relatively fat marine species, enzymatic and non-enzymatic lipid deterioration has shown to occur and become an important factor of fish acceptance (Harris and Tall, 1994; Erickson, 1997). On the other hand, frozen product quality has shown to depend on a great extent on adequate handling and storage techniques carried out on-board and before the freezing step is accomplished (Toledo-Flores and Zall, 1992; Olafsdóttir et al., 1997; Undeland and Lingnert, 1999).

One of such on-board treatments is gutting (Kelman, 1982; Tejada and Huidobro, 2002). Guts are known to be a reservoir of powerful digestive enzymes and bacteria that can spoil the flesh, resulting in unacceptable odours and flavours. As a result of gutting, many studies report an extension of shelf life during fish species chilling (Vyncke, 1980; Rodríguez et al. 1999; Oehlenschläger and Rehbein, 2000), although other reports show that gutting creates another cut surface or potential bacterial contamination and does not benefit the shelf life (Ravesi et al., 1985; Gelman et al., 1990).

As a previous treatment of other processes than chilling, gutting information is scarce and result conclusions uncertain. Thus, previous anchovy gutting has shown to delay the ripening process when compared to fresh nobbed fish (Pérez-Villarreal and Pozo, 1992; Mendes et al., 1999). About frozen storage, previous gutting showed to maintain sensory acceptance and to reduce volatile amine content in lean fish (Botta et al., 1982), while no effect was observed on quality for fatty fish (Karaçam and Boran, 1996). 
The present work concerns the horse mackerel and its commercialisation as a frozen product. Horse mackerel (Trachurus trachurus) is a medium-fat content fish abundant in the Northeast Atlantic that has recently captivated a great attention (Zimmermann and Hammer, 1999; FAO, 2002). The study is aimed to evaluate the effect of a previous gutting on the stability of horse mackerel lipids during the frozen storage. For it, chemical and sensory damage indices were studied to assess rancidity development.

\section{MATERIALS AND METHODS}

Raw fish, sampling and processing

Fresh horse mackerel (Trachurus trachurus) were obtained $10 \mathrm{hr}$ after catching in November 2001 in the Atlantic Galician coast. The length of the fish was in the range $18-24 \mathrm{~cm}$; the weight was in the range 250-280 g.

Upon arrival in the laboratory, one half of the fish $(n=56)$ was directly packaged in polyethylene bags and immediately frozen at $-80^{\circ} \mathrm{C}$. The other half $(n=56)$ was eviscerated in an isothermal room at $4^{\circ} \mathrm{C}$, allowed to bleed during 20-30 min, carefully washed, packaged in polyethylene bags and frozen at $-80^{\circ} \mathrm{C}$. After 24 hours at $-80^{\circ} \mathrm{C}$, all fish were placed at $-20^{\circ} \mathrm{C}$. Sampling was undertaken at $0,1,3,5,7,9$ and 12 months of frozen storage at $-20^{\circ} \mathrm{C}$. At each sampling time and for each kind of processing, eight different fishes were employed for carrying out the chemical and sensory analyses.

\section{Composition analyses}

For all chemical determinations, three independent batches were studied separately to assess the statistical study.

Water content was determined by weight difference between the homogenised white muscle (1-2 g) and after $24 \mathrm{hr}$ at $105^{\circ} \mathrm{C}$. Results were calculated as g water/100 g muscle.

Lipids were extracted from the white muscle by the Bligh and Dyer (1959) method. Quantification results are expressed as g lipids/100 g wet muscle.

\section{Chemical lipid damage measurements}

Free fatty acids (FFA) content was determined by the Lowry and Tinsley (1976) method based on complex formation with cupric acetate-pyridine. Results are expressed as g FFA/100 g lipids.

Peroxide value (PV) expressed as meq oxygen/kg lipid was determined by the ferric thiocyanate method (Chapman and McKay, 1949).

The thiobarbituric acid index (TBA-i) was determined according to Vyncke (1970). Results are expressed as mg malondialdehyde/kg fish sample.

\section{Interaction compounds formation}

Fluorescence formation (Perkin-Elmer LS 3B) at 327/415 nm and 393/463 nm was studied as described earlier (Aubourg et al., 1998; Aubourg et., 1999). The relative fluorescence (RF) was calculated as follows: $R F=F / F_{\text {st }}$, where $F$ is the fluorescence measured at each excitation/emission pair, and $\mathrm{F}_{\text {st }}$ is the fluorescence intensity of a quinine sulphate solution $\left(1 \mu \mathrm{g} / \mathrm{ml}\right.$ in $\left.0.05 \mathrm{M} \mathrm{H}_{2} \mathrm{SO}_{4}\right)$ at the corresponding wavelength. The following fluorescence ratio (FR) was calculated: $\mathrm{FR}=\mathrm{RF}_{393 / 463 \mathrm{~nm}} / \mathrm{RF}_{327 / 415 \mathrm{~nm}}$, that was studied on the lipid extract. 


\section{$\underline{\text { Sensory analysis }}$}

Sensory analysis was conducted by a trained taste panel consisting of six to nine experienced judges. For each sample analysis, fillets of five fishes were cooked in plastic bags in a water bath. Odour and taste were then evaluated for Freshness (from 100 to 0; highly fresh to not fresh at all) and Rancidity (from 0 to 100; no rancidity at all to stage where no increase of rancidity is possible) (Aubourg et al., 2002). Scores among panellists were averaged.

\section{$\underline{\text { Statistical analyses }}$}

Data from the different chemical and sensory quality measurements were subjected to ANOVA one-way method and correlation analysis (linear and non-linear) $(\mathrm{p}<0.05)$ (Statsoft, 1994); comparison of means was performed using a least-squares difference (LSD) method.

\section{RESULTS AND DISCUSSION}

Water contents of the different fish samples ranged between 74.4 and $77.5 \%$. Lipid contents ranged between 1.80 and $4.50 \%$. Content variations in both constituents may be explained as a result of individual fish to fish variation, and not arising from gutting handling or frozen storage. Comparison of the present results with previous research showed a higher water content in horse mackerel than in fattier fish species (Aubourg et al., 1998) and a lower water content than for leaner fish species (Aubourg et al., 1999) in accordance with an inverse ratio between water and lipid matter.

Actual lipid contents were higher than those obtained in previous research for horse mackerel (Aubourg et al., 2002; Aubourg and Ugliano, 2002), according to the seasonal distribution of lipid content that has shown a maximum content in Autumn (Hardy and Keay, 1972; Bandarra et al., 2001).

\section{Lipid hydrolysis}

Comparison between gutted and ungutted samples only afforded significant $(\mathrm{p}<0.05)$ differences at month 12 (Table 1). At this time, gutted fish showed a lower hydrolysis development. This result can be explained as a result of discarding the viscera that are known to include a high content on hydrolytic enzymes (Scott et al., 1986; Sotelo and Rehbein, 2000). As a result of frozen storage a general increase in lipid hydrolysis was observed for both kinds of samples leading to good linear correlation values $\left(r^{2}=0.94\right.$ and $r^{2}=0.97$, respectively; Table 2$)$ with the storage time.

Examining the extent of lipid hydrolysis was deemed important to the study because a high degree of lipid hydrolysis has already been observed in horse mackerel during frozen storage (Simeonidou et al., 1997; Aubourg and Ugliano, 2002; Aubourg et al., 2002) and FFA formation has previously proved a great incidence on lipid oxidation (Yoshida et al., 1992) and protein denaturation (Mackie, 1993; Sikorski and Kolakowska, 1994).

\section{Lipid oxidation}

Peroxides assessment provided a very different behaviour in both kinds of samples (Table 1). Ungutted fish showed a slow increase with time; compared to the month 0 value, a significant $(\mathrm{p}<0.05)$ increase was only observed at months 9 and 12 . However, gutted fish underwent a fast peroxides formation at month 5 , reached a maximum mean value at month 7 and then decreased as a result of peroxides breakdown. Comparison of both kinds of samples showed a higher $(\mathrm{p}<0.05)$ oxidation development value for gutted fish at 1, 5, 7 and 9 months of storage. Fair non-linear 
correlation values were obtained for gutted and ungutted fish $\left(r^{2}=0.78\right.$ and $r^{2}=0.90$, respectively; Table 2) when compared to the storage time.

Analysis of the thiobarbituric acid reactive substances (TBARS) led to a higher $(\mathrm{p}<0.05)$ oxidation level for gutted samples at months 3, 7, 9 and 12 (Table 1), according to the previously commented peroxide development. TBARS formation did not show a regular pattern with time for ungutted fish; however, a good agreement with storage time was obtained for the gutted samples $\left(r^{2}=0.93\right.$, logarithmic fitting; Table 2).

\section{Interaction compounds formation}

Formation of fluorescent products as a result of interactions between lipid oxidation compounds (peroxides and TBARS) and nucleophilic molecules (proteins, peptides, etc) (Aubourg, 1993; Howell, 1995) has been reported to be an interesting way of following lipid oxidation development during fish processing (Hasegawa et al., 1992; Aubourg, 1999).

Differences between both kinds of treatments could not be appreciated during the first part (up to month 5) of the experiment (Table 1). After that time, when peroxide and TBARS formation was important, a higher $(\mathrm{p}<0.05)$ fluorescence development could be obtained for the gutted fish at months 7, 9 and 12 .

Detection of fluorescence formation showed a general increasing tendency for mean values in both kinds of samples, except for the latest period (months 9-12) in gutted fish. Compared to the month 0 value, gutted fish samples provided a significant $(p<0.05)$ increase at month 3 , while ungutted ones showed a higher FR value $(p<0.05)$ at month 5. Good correlation values with storage time were obtained for ungutted and gutted samples $\left(r^{2}=0.87, r^{2}=0.90\right.$, respectively; Table 2$)$.

\section{Sensory analysis}

Odour was analysed according to freshness loss (Figure 1) and rancidity development (Figure 2). In both cases, good values were observed for all kinds of samples till month 5 . Then, at month 7 , a sharp quality decrease $(\mathrm{p}<0.05)$ was detected for freshness and rancidity assessments, being stronger in the case of gutted fish. Then, till the end of the experiment, better sensory acceptance was obtained for ungutted samples. Fair correlation values with storage time were obtained for Freshness in ungutted and gutted fish $\left(r^{2}=-0.83\right.$ and $r^{2}=-0.88$, respectively; Table 2$)$.

Similar results were obtained for the taste assessment, where freshness loss (Figure 3) and rancidity development (Figure 4) were checked. Fresh taste assessment provided a significantly $(\mathrm{p}<0.05)$ higher value for ungutted fish at months 7, 9 and 12 . Both kinds of samples showed a gradual freshness loss with time. A good correlation of freshness value with storage time was obtained for ungutted and gutted fish $\left(\mathrm{r}^{2}=-0.82\right.$ and $r^{2}=-0.92$, respectively; Table 2 ). Rancidity taste did not provide significant differences between both treatments till month 5 . Then (7-12 months) a higher rancidity development was observed for gutted fish.

\section{FINAL COMMENTS}

Present results (chemical and sensory) have shown a higher lipid oxidation development as a result of gutting. It can be concluded that in spite of avoiding the autolytic spoilage and microbial development (Scott et al., 1986; Sotelo and Rehbein, 2000), gutting has provided a new cut surface that facilitates the non-enzymatic lipid oxidation, and accordingly the non-enzymatic browning development (Cheftel and 
Cheftel, 1976; Pokorný, 1981). As a result, gutting is not recommended as a previous step to frozen storage for the present medium-fat content fish species.

\section{Acknowledgements}

The authors thank Mr. Marcos Trigo and Mr. José M. Antonio for technical assistance and are grateful for the financial support provided by the Cooperation Program (2001-2002) Germany-Spain (MCyT-INIA) of Agricultural Research and the Comisión Interministerial de Ciencia y Tecnología (project ALI 99-0869; 2000-2002). 


\section{REFERENCES}

Aubourg S, Rey-Mansilla M, Sotelo C (1999) Differential lipid damage in various muscle zones of frozen hake (Merluccius merluccius). Z Lebensm Unters Forsch 208:189-193

Aubourg S, Sotelo C, Pérez-Martín R (1998) Assessment of quality changes in frozen sardine (Sardina pilchardus) by fluorescence detection. J Am Oil Chem Soc 75: $575-580$

Aubourg, S. (1993) Review: Interaction of malondialdehyde with biological molecules: New trends about reactivity and significance. Int. J. Food Sci. Technol. 28: 323335.

Aubourg, S. (1999). Review: Recent advances in assessment of marine lipid oxidation of marine lipid oxidation by using fluorescence. J. Amer. Oil Chem. Soc. 76: 409-419.

Aubourg, S.; Lehmann, I.; Gallardo, J. Effect of previous chilled storage on rancidity development in frozen horse mackerel (Trachurus trachurus). J. Sci. Food Agric. 2002, 82, 1764-1771.

Aubourg, S.; Ugliano, M. Effect of brine pre-treatment on lipid stability of frozen horse mackerel (Trachurus trachurus). Eur. Food Res. Technol. 2002, 215, 91-95.

Bandarra, N.; Batista, I.; Nunes, M.; Empis, J. Seasonal variation in the chemical composition of horse mackerel (Trachurus trachurus). Eur. Food Res. Technol. 2001, 212, 535-539.

Bligh E, Dyer W (1959) A rapid method of total extraction and purification. Can J Biochem Physiol 37: 911-917

Botta J, Downey A, Lauder J, O’Neill M (1982) Chemical and sensory assessment of roundnose grenadier (Macrourus rupestris) subjected to long term frozen storage. J Food Sci 47:1670-1674

Chapman R and McKay J, The estimation of peroxides in fats and oils by the ferric thiocyanate method, J Am Oil Chem Soc 26:360-363 (1949).

Cheftel J, Cheftel H (1976) Introducción a la Biología y Tecnología de Alimentos. Editorial Acribia, Zaragoza (Spain), pp 263-290, 291-308

Erickson M, Antioxidants and their application to frozen foods. In Quality in frozen food, Ed by Erickson M and Hung Y-C, Chapman and Hall, New York (USA), pp 233-263 (1997).

FAO, Fishery statistics, Yearbook 2000, Vol. 90/1. Food and Agriculture Organization of the United Nations, Rome (Italy), 2002, p. 247.

Gelman A, Pasteur R, Rave M (1990) J Sci Food Agric 52:231-247

Hardy, R.; Keay, J. Seasonal variation in the chemical composition of Cornish mackerel, Scomber scombrus (L.), with detailed references to the lipids. J. Food Technol. 1972, 7, 125-137.

Harris P, Tall J (1994) Rancidity in fish. In Allen J C, Hamilton R J (eds) Rancidity in foods. Chapman and Hall, London (UK), pp 256-272

Hasegawa, K., Endo, Y. and Fujimoto, K. (1992). Oxidative deterioration in dried fish model systems assessed by solid sample fluorescence spectrometry. J. Food Sci. 57: 1123-1126.

Howell N, Interaction of proteins with small molecules. In Ingredient interactions Effects on food quality, Ed by Gaoucar A, Marcel Dekker, New York (USA), pp 269-289 (1995).

Karaçam H, Boran M (1996) Quality changes in frozen whole and gutted anchovies during storage at $-18^{\circ} \mathrm{C}$. Int J Food Sci Technol 31:527-531 
Kelman J (1982) Handling wet fish at sea. In Fish:Handling and Processing, ed. By Aitken A, Mackie I, Merritt J, Windsor M. Ministry of Agriculture, Fisheries and Food, Torry Research Station, Edingburgh (GB), pp 28-41

Lowry R, Tinsley I (1976) Rapid colorimetric determination of free fatty acids. J Am Oil Chem Soc 53: 470-472

Mackie I, The effects of freezing on flesh proteins, Food Rev Int 9:575-610 (1993).

Madrid A, Madrid J and Madrid R, Tecnología del pescado y productos derivados, Madrid Vicente A, Ediciones y Mundi-Prensa Libros, S A, Madrid (Spain), pp 45-103 (1994).

Mendes R, Gonçalves A, Nunes M (1999) Changes in free amino acids and biogenic amines during ripening of fresh and frozen sardine. J Food Biochem 23:295-306

Oehlenschlaeger J, Rehbein H (2000) Shelf life of gutted and ungutted ocean perch (Sebastes marinus and Sebastes mentella) during ice storage. In $30^{\text {th }}$ WEFTA, Torshavn, Faroe Islands, June 2000

Olafsdóttir G, Martinsdóttir E, Oehlenschläger J, Dalgaard P, Jensen B, Undeland I, Mackie I, Henehan G, Nielsen J and Nilsen H, Methods to evaluate fish freshness in research and industry, Trends Food Sci Technol 8:258-265 (1997).

Pérez-Villarreal B, Pozo R (1992) Ripening of the salted anchovy (Engraulis encrasicholus): Study of the sensory, biochemical and microbiological aspects. In Quality assurance in the fish industry (H.Huss et al. eds.). Elsevier Science Publishers B. V. pp. 157-167

Pigott $G$ and Tucker B, Science opens new horizons for marine lipids in human nutrition, Food Rev Intern 3:105-138 (1987).

Pokorný J, Browning from lipid-protein interactions, Prog Food Nutr Sci 5:421-428 (1981).

Ravesi E, Licciardello J, Tuhkunen B, Lundstrom R (1985) Mar Fish Rev 47:48-67

Rodríguez C, Besteiro I, Pascual C (1999) Biochemical changes in freshwater rainbow trout (Oncorhynchus mykiss) during chilled storage. J Sci Food Agric 79:14731480

Scott D, Fletcher G, Hogg M, Ryder J (1986) Comparison of whole with headed and gutted orange roughy stored in ice: Sensory, microbiology and chemical assessment. J. Food Sci. 51:79-86

Sikorski, Z.; Kolakowska, A. Changes in protein in frozen stored fish. In Seafood proteins. Sikorski Z.; Sun Pan, B.; Shahidi, F., Eds. Chapman \& Hall. New York (USA), 1994, pp. 99-112.

Simeonidou S, Govaris A and Vareltzis K, Effect of frozen storage on the quality of whole fish and fillets of horse mackerel (Trachurus trachurus) and Mediterranean hake (Merluccius mediterranean), Z Lebensm Unters Forsch 204:405-410 (1997).

Sotelo, C. and Rehbein, H. (2000) TMAO-degrading enzymes. In Seafood enzymes. Edited by N. Haard and B. Simpson. Marcel Dekker, Inc. New York (USA) and Basel (Switzerland), pp. 167-190.

Statsoft (1994) Statistica for Macintosh. Statsoft and its licensors, Tulsa, Oklahoma (USA)

Tejada M, Huidobro A (2002) Quality of farmed gilthead seabream (Sparus aurata) during ice storage related to the slaughter method and gutting. Eur Food Res Technol 215:1-7

Toledo-Flores L and Zall R, Methods for extending the storage life of fresh tropical fish. In Advances in seafood biochemistry, Ed by Flick $G$ and Martin R, Technomic, Lancaster, pp 233-243 (1992). 
Undeland I and Lingnert $\mathrm{H}$, Lipid oxidation in fillets of herring (Clupea harengus) during frozen storage. Influence of prefreezing storage. J Agric Food Chem 47:2075-2081 (1999).

Vyncke W (1980) Quality assessment of gutted and ungutted gurnard (Trigla spp.) by organoleptic and objective methods. Z Lebensm Unters Forsch 71:352-354

Vyncke W, Direct determination of the thiobarbituric acid value in trichloracetic acid extracts of fish as a measure of oxidative rancidity, Fette Seifen Anstrichm 72:1084-1087 (1970).

Yoshida H, Kondo I, Kajimoto G (1992) Participation of free fatty acids in the oxidation of purified soybean oil during microwave heating. J. Am Oil Chem Soc 69:1136-1140.

Zimmermann C and Hammer C, On the Biology of the horse mackerel in North and North-East Atlantic, Inf Fischwirtsch Fischereiforsch 46:14-23 (1999). 


\section{FIGURE LEGENDS}

Figure 1: Fresh odour assessment during frozen storage of ungutted and gutted horse mackerel

Figure 2: Rancid odour assessment during frozen storage of ungutted and gutted horse mackerel

Figure 3: Fresh taste assessment during frozen storage of ungutted and gutted horse mackerel

Figure 4: Rancid taste assessment during frozen storage of ungutted and gutted horse mackerel

\section{TABLE 2}

Correlation values* between frozen storage time and quality (chemical and sensory) indices

\begin{tabular}{|c|c|c|}
\hline Index & Ungutted & Gutted \\
\hline Free Fatty Acids & 0.97 & 0.94 \\
\hline Peroxide Value & 0.88 & 0.76 \\
& $(0.90)^{\mathrm{b}}$ & $(0.78)^{\mathrm{a}}$ \\
\hline Thiobarbituric Acid Index & 0.65 & 0.89 \\
& $(0.67)^{\mathrm{a}}$ & $(0.93)^{\mathrm{a}}$ \\
\hline Fluorescence Ratio & 0.87 & 0.88 \\
& & $(0.90)^{\mathrm{a}}$ \\
\hline Fresh Odour & -0.74 & -0.88 \\
\hline Rancid Odour & $(-0.83)^{\mathrm{a}}$ & 0.72 \\
\hline Fresh Taste & 0.65 & -0.92 \\
\hline Rancid Taste & $(0.67)^{\mathrm{a}}$ & 0.85 \\
\hline
\end{tabular}

* Linear correlations are expressed in all cases. Logarithmic ${ }^{\mathrm{a}}$ and exponential ${ }^{\mathrm{b}}$ fitting values are indicated in brackets when superior to the corresponding linear one. 


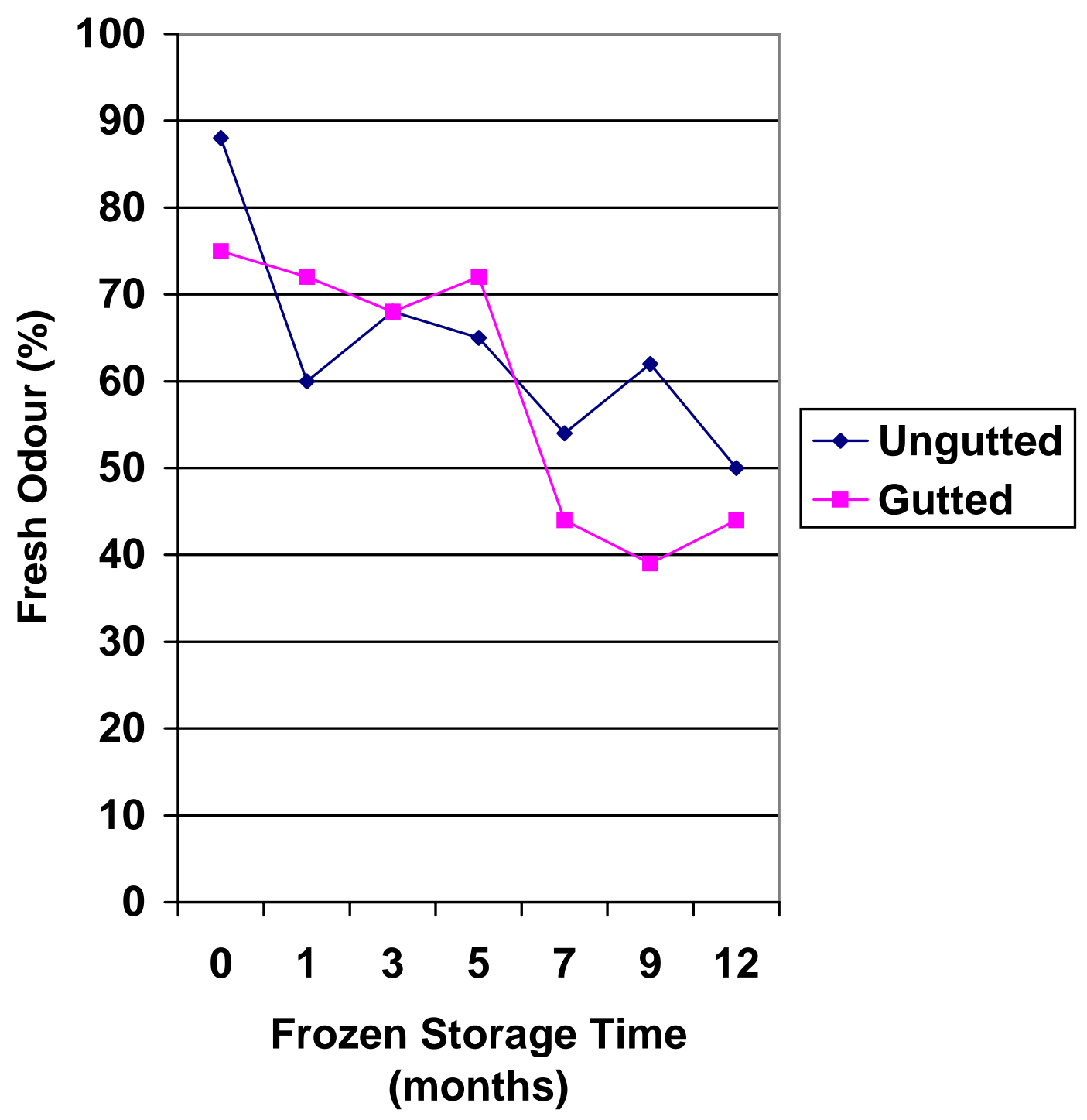




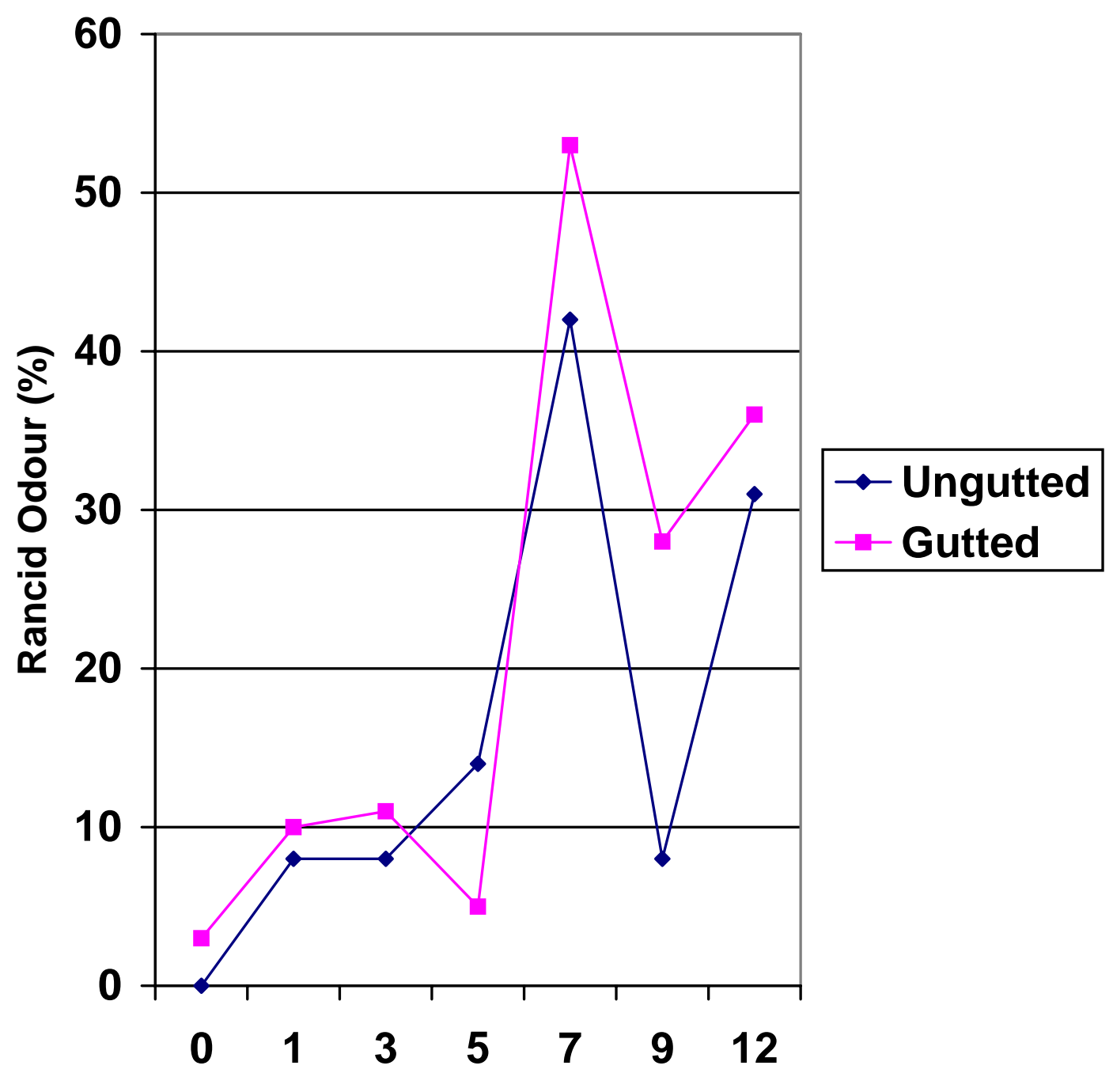

Frozen Storage Time (months) 


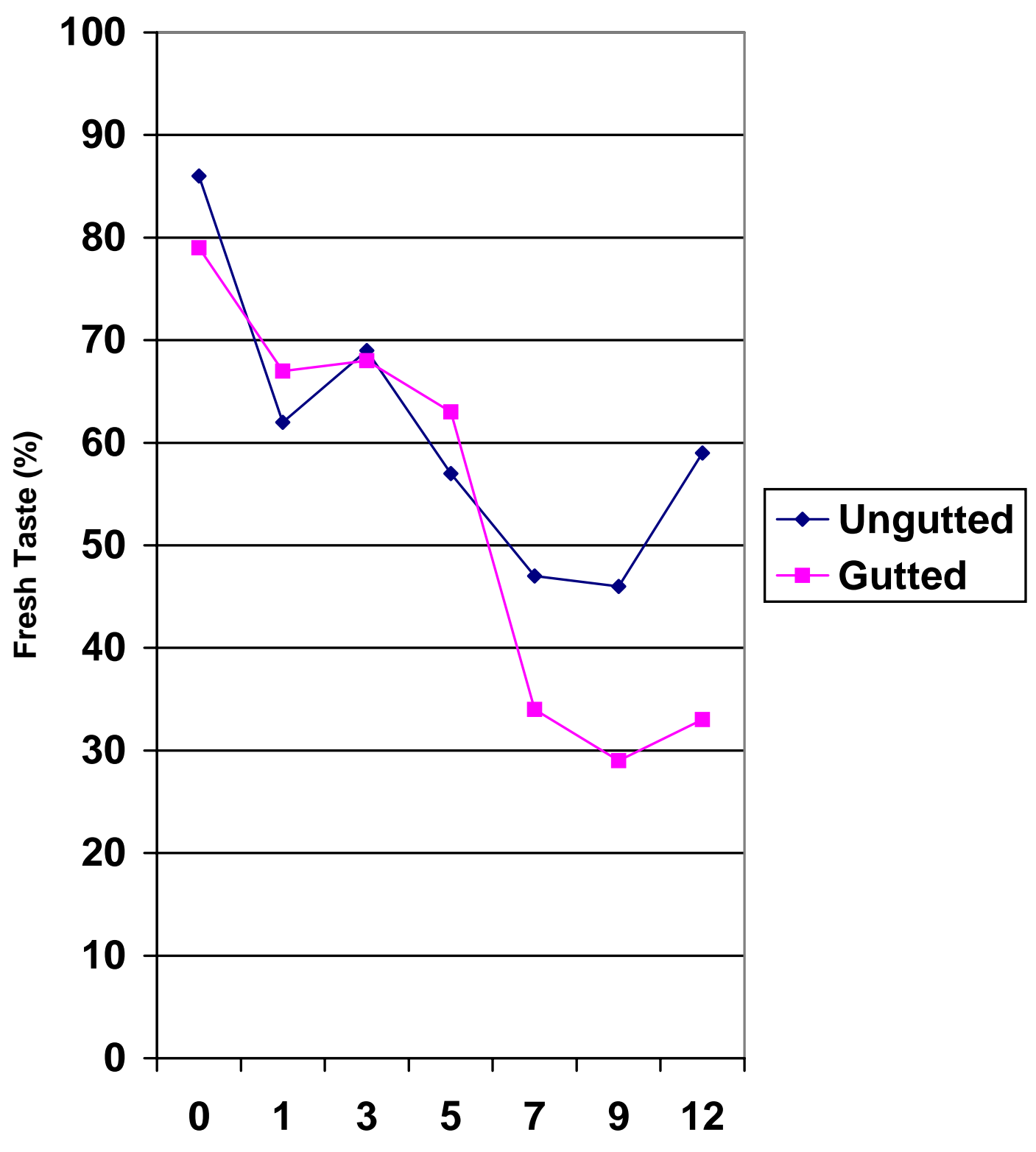

Frozen Storage Time (months) 


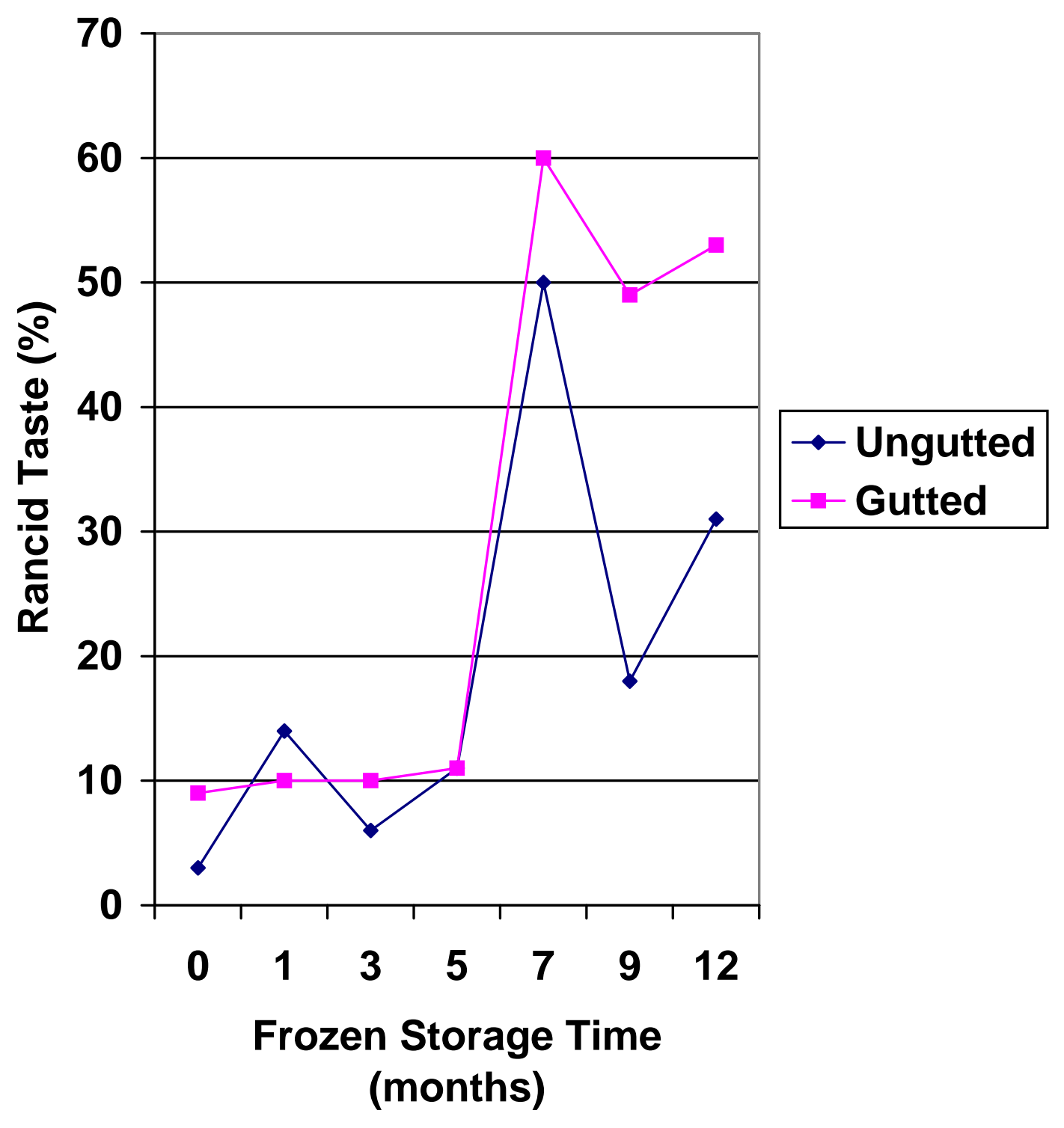


TABLE 1

Biochemical analysis of lipid damage during frozen storage of ungutted and gutted horse mackerel*

\begin{tabular}{|c|c|c|c|c|c|c|c|c|}
\hline & \multicolumn{2}{|c|}{ Free Fatty Acids } & \multicolumn{2}{|c|}{ Peroxide Value } & \multicolumn{2}{|c|}{ Thiobarbituric Acid Index } & \multicolumn{2}{|c|}{ Fluorescence Ratio } \\
\hline 1 & $0.40 \mathrm{a}$ & $0.67 \mathrm{a}$ & ${ }^{\mathrm{y}} 1.27 \mathrm{a}$ & ${ }^{\mathrm{z}} 2.65 \mathrm{ab}$ & $0.26 \mathrm{ab}$ & 0.62 bc & $0.46 \mathrm{ab}$ & $0.52 \mathrm{a}$ \\
\hline 5 & $1.05 \mathrm{~b}$ & $1.40 \mathrm{~b}$ & ${ }^{\mathrm{y}} 2.78 \mathrm{ab}$ & ${ }^{\mathrm{z}} 8.38 \mathrm{~cd}$ & $0.50 \mathrm{~b}$ & 0.75 bcd & 0.73 bc & $1.09 \mathrm{bc}$ \\
\hline 7 & $1.64 \mathrm{C}$ & $1.85 \mathrm{bc}$ & ${ }^{\mathrm{y}} 2.54 \mathrm{ab}$ & ${ }^{\mathrm{z}} 12.60 \mathrm{e}$ & ${ }^{\mathrm{y}} 0.42 \mathrm{~b}$ & ${ }^{\mathrm{z}} 0.73$ bcd & ${ }^{\mathrm{y}} 0.73 \mathrm{bc}$ & ${ }^{\mathrm{z}} 1.48 \mathrm{~d}$ \\
\hline 9 & $2.03 \mathrm{~d}$ & $1.92 \mathrm{c}$ & ${ }^{\mathrm{y}} 4.23 \mathrm{~b}$ & ${ }^{\mathrm{z}} 11.40 \mathrm{de}$ & ${ }^{\mathrm{y}} 0.49 \mathrm{~b}$ & ${ }^{\mathrm{z}} 1.07 \mathrm{~d}$ & ${ }^{\mathrm{y}} 0.93 \mathrm{bc}$ & ${ }^{\mathrm{z}} 1.31 \mathrm{~cd}$ \\
\hline
\end{tabular}

* Mean values of three independent determinations. For each index, mean values preceded by different superscripts (y-z) indicate significant $(p<0.05)$ differences between both treatments. For each column, means followed by different letters (a-e) are significantly different $(\mathrm{p}<0.05)$. 